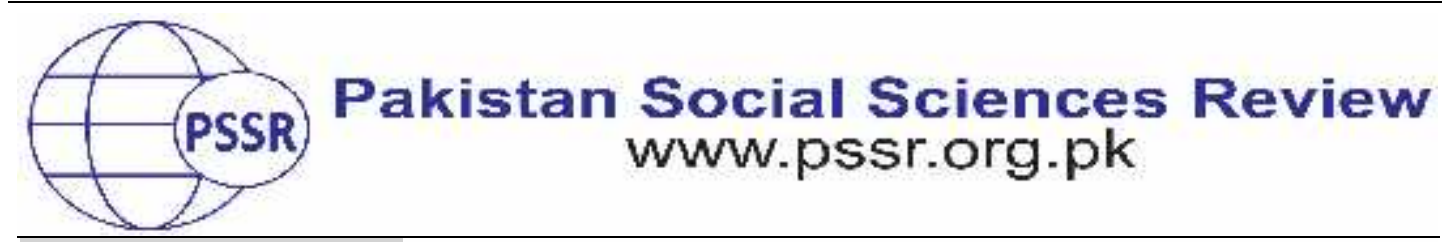

RESEARCH PAPER

\title{
Historical Analysis of Federalism in Pakistan from Partition to 1973 Constitution
}

\section{Kashif Iqbal Rana*1 Imran Wakil ${ }^{2}$ Nosheen Ashraf ${ }^{3}$}

1. M.Phil. Political Science, Government College University Faisalabad, Punjab, Pakistan

2. Lecturer, Department of International Relations, Government College University Faisalabad, Punjab, Pakistan

3. M.Phil. Political Science, Government College University Faisalabad, Punjab, Pakistan

\begin{tabular}{|c|c|}
\hline PAPER INFO & ABSTRACT \\
\hline Received: & The history of federalism in Pakistan has been discussed in this \\
\hline July 3 & aper. The inception of Pakistan foundations of federal systen \\
\hline $\begin{array}{l}\text { Accepted: } \\
\text { November 04, } 2021\end{array}$ & \\
\hline Online. & \\
\hline er 06, 2021 & context of governance in Pakistan has been laid out in the paper. \\
\hline $\begin{array}{l}\text { Key } \\
18^{\text {th }}\end{array}$ & The paper examines comprehensively the constitutional efforts \\
\hline 1956 & lape of 1956, 1962, and \\
\hline Constitu & \\
\hline & \\
\hline $\begin{array}{l}\text { Centre-Prov1 } \\
\text { Relations }\end{array}$ & with its effects to the federalism and federal practices in $t$ \\
\hline $\begin{array}{l}\text { Federalism, } \\
\text { Pakistan }\end{array}$ & country. The mechanism of federalism as a key method to the \\
\hline *Corresponding & solutions of all the problems in Pakistan especially with \\
\hline $\begin{array}{l}\text { Author } \\
\text { kashifghaffar86@gm } \\
\text { ail.com }\end{array}$ & provinces obtaining more power has also been discussed in the \\
\hline
\end{tabular}

\section{Introduction}

With the divide of Sub-continent the world saw emergence of two new states. Pakistan and India since then become important strategic states in the cold war era, especially Pakistan. With its emergence the state of Pakistan has been a federal state from political perspective. When we talk about federation, it is meant that a governmental system that only works for national integrity but also for its units, provinces for example. But these theoretical perspectives have not been accomplished by Pakistan completely. This failure has led to divide, non-co-existence and contentions between provinces and the center given any circumstances since the inception. The constitutional history has also been failed to strengthen ties between centre and units. It is clearly evident that it took the state seven years to form its first 
constitution in 1956 but revoked in 1958, then in 1962, when second constitution was drawn and adopted but also failed as it was also abrogated by military coup. Even so that the constitution of 1973, which was accepted and being followed till has also not been able to eradicate and solve the issues between center and units (Iqbal, 2020).

As a matter of fact, it allowed the units and centre not just to misread the constitution, but also to reinterpret it as per to their self-narrated interpretations. Each avoided one another's political and economic privileges. Furthermore, the new laws of the constitution, which were supposed to protect independent governance, allowed the centre the freedom to reject freedom of provinces and so exploit it.

Then, the constitution has not been seen and followed as per its genuine spirit. A political science student attentively examines examples such as the conflict among Sindh's provincial government, other provinces and the state government, that falls within Article 147. The country's constitution, implemented by the 3rd state legislature in 1973, has been suspended two times by military dictators, first by General Zia in 1977 (1977 - 1985), and then by General Pervaiz Musharraf in 1999 (1999 - 1985), and when it was 'restored' in 1985 and 2002, the military dictators modified this in aspects which completely transformed its Shariah and federal identity. On these occasions, however one modification gave the president the authority to dismiss the house of representatives of the national parliament. With all of this power and authority of heads of state - a desk supplanted by two dictatorial regimes somewhere at time of trying to restore the charter - the resulting legislative powers had been compelled to provide guaranteed by the constitution to shield to the actions of revocation of the charter, as well as all other acts of the military juntas during in the time frame between both the suspension and rehabilitation of the constitution, through the eighth and 17th Legislative changes on both occurrences.

A major breakthrough came out with the eighteenth Amendment in Constitution of 1973, that was voted unanimously by the National Assembly on April 8, 2010, was a significant step forward in Pakistani federal system. The president's power was drastically limited as a result of this legislation. It allowed the provinces additional authority while returning responsibilities to National assembly. The Senate passed the eighteenth Amendment on April 16th in 2010, and it turned out to be an act of the parliament (Iqbal, 2020).

\section{Literature Review}

"A Glance at Federalism of Pakistan in perspective of Linguistic, Economic, Fiscal and Ethnic Dimensions" by Ghulam Mustafa (2019) Federal system is a political system wherein the participating states and subdivisions inside a political body divide respective rights and responsibilities in order to control pluralism and language variation. Federal system is defined as a huge assortment of legislative measures designed to relieve confidence and heterogeneity by protecting the national 
uniqueness of various organisations and segments, and also assuring social or political involvement to take into consideration local interests. According to scholars in the field, Pakistan's central government has been subjected to a variety of military coups enforced by different authorities or army generals. They paid scant heed to the country's federal divides because minority groups were not involved to create greater autonomy. Instead of political administrations, the army generals and governmental bureaucracy have traditionally ruled this federal structure. Military coups have also been used to postpone and abrogate Pakistan's constitutions in 1956, 1962, and 1973 on several times. With the dominant framework of the federal govt, local assemblies have been dissolved for a long time, and federal requirements for actions have been imposed. The challenges and tensions that arise in the federal structure of the nation as a consequence of the intermediate monopolies are examined in this text. This study further discusses legislative changes that have occurred on various situations in the past.

"Politics of New Provinces In Pakistan: Prospects and Challenges" by Saman Zulfqar (2012) even though Pakistan is a federal country, he claims that the concept of federation has still not been fully defined. Demands for regional economic autonomy and resources distribution are increasing, as are conflicts here between federal government and the units. The Republic's challenges have taken on a whole new significance with the recent desire for more areas. Despite the fact that both opponents and proponents of the petition have valid information, developing innovative provinces is challenging. Only by parliamentary and internal procedures may new counties be formed. This one should be researched in order to continue the research and obtain the needed results in order to complete the research in a positive manner.

"The Endemic Crisis of Federalism in Pakistan" by Raza Ahmad (2010) the problem with federation in Pakistan and the presidential state is discussed in this text. It begins with a theoretical investigation of federalism's notions before moving on to evaluate and then analyse Federalism's elements and timeline in Pakistan in the utmost appealing and practical method possible. The report might also look into why the Federation Structural Accord of democracy hasn't been developed, as well as how the seventh NFC award may be indicative of change of paradigm, but also how the 18th amendment to the charter could be significant of a transition in the trend. The paper concludes with a discussion on Pakistan's progression toward federation, as well as truth and facts.

"Federalism in Pakistan: Problems \& Prospects" by Mansoor Akbar Kundi (2002) has narrated that since Pakistan's founding in 1947, relationships here between provincial and federal governments have been a source of political and legislative dispute. Pakistan, which is subdivided into four regions (provinces), has indeed been overshadowed by Punjab, the biggest of the four units (provinces), that has a majority 
of the country's administration and military. Rest of the 3 components have expressed their dissatisfaction with the central govt's transmission and distribution of resources and have called for additional independence and democratic constraints. Pakistan's Templar nature, with the army dominating the nation throughout the majority of its history, have exacerbated the nation's federation challenges.

\section{Federalism in Pakistan: Historical Analysis}

Federalism is indeed a governmental framework or design in which the government administration elements trade economic and political authorities, responsibilities, and assets inside a collaborative fashion. Nevertheless, advocates of cultural minorities and secular narrative strive to remove the populace of components from participation (Tamuno, 1998). Nevertheless, in order to turn cultural and linguistic diversity into progress, federation recommends suitable governance structures by ensuring political and economic influence and the manner of infrastructure along with resource exchange chosen. These institutional arrangements not only strengthen the organization, and yet also enhance regional freedom by performing forth key governance actions and boosting political and economic advantages. Federalisation, throughout this way and thereby, preserves the federal unit integrity (Naseer, 2007). Many Political and socio - economic experts say that federation is the greatest method to resolve differences and conflicts amongst distinct political entities, as well as to provide venues for reform to confront and handle reasonable issues (Ariyo, 2003).

The contributing components have to demonstrate a desire to work together in federalism for a shared interest and a powerful willingness for safeguarding political and social, regional and ethnic individuality and ideology. Furthermore, federal divisions will give some room for political and economic activities to the federal government in its domain. These really are complicated proposals those can make groups coherent and reticent to secessionist impulses. These are complex proposals. In states such as Pakistan, which actually underwent separation during 1971. Federalism and provincial autonomy studies are important (Naseer, 2007).

\section{Modes of Federalism}

Federalization includes two basic methods for putting the concept into effect. Hybrid federation is mentioned in the first approach. In this concept, the Charter is meant to build 2 separate and independent tiers of governmental processes. The political and economic components are characterized below an accepted constitutional authority with explicit functions and responsibilities, and the contacts across federation and its other components, as well as among subdivisions, are enhanced. The second strategy is known as 'cooperative federalism.' This strategy attempts to unite several branches of government into a unified, coordinated, suitable, and long-term political structure. This form of federation encourages 
collaboration and coordination across various levels of government. Proficiency and disagreement in related functions and collaborations are less important than various states of governance (Ariyo, 2003).

\section{The Federation and Provincial Autonomy}

Pakistan was disintegrated in 1971, and following that East Pakistan incident Pakistan adopted the constitution of 1973 that was implemented and established. Thus pro term 1972 constitution of Pakistan was replaced. This constitution wellmaintained the federal structure of state, yet parliamentary system of two-houses was established that was not present in the preceding charters. The National Assembly (Lower House) and Senate (Upper House) were established. The National Assembly had 200 members those were directly elected by general elections and Senate had 60 members. In the beginning, the charter of 1973 created the federal mechanism in Pakistan. Duties had been distributed among federating unit and similar bodies. The federal list had 67 issues, whereas state legislators had to make the rules on the corresponding list. Nevertheless, authority of the central administration had to be operative along with superlative in what so ever conflict of economic or political nature in accordance with article 143 (Kundi \& Jahangir, 2002).

\section{Constitutional History of Federation in Pakistan}

When the World War 2 ended, the British Empire gave freedom to their colony of Sub-continent because it was not possible for them to control the region any further. Thus Pakistan and India came into existence in 1947. Initially the Indian Government Act of 1935 was amended accordingly and adopted by Pakistan to run the state affairs. Later, after 9 years gap, Pakistan adopted 1956 Constitution which flopped and revoked in 1958. Thus the journey began.

\section{Government of India Act, 1935}

The Government of India Act. 1935 was created after a long procedure of changes and modifications to the previous constitutions. The act was passed by the British Parliament and authorized after the freedom struggle in the region. Pakistan had no proper constitution in the start thus this act was adopted to govern the matters of the state after a few basic and necessary amendments. This act gave far reaching powers to the president, including the authority to suspend federal and parliamentary governments of the provinces. This similarly contained a "parity formula" that would govern the depiction of West and East Pakistan in National Assembly on the parity basis and not on the basis of population (History of Pakistan, 2021). 


\section{Indian Independence Act. 1947}

Following freedom, the Indian government Law, 1935, had become the functional charter of Pakistan via Article 8(1) of the Independence Act of India, 1947, with only minor revisions until the New Parliament drafted a fresh charter. The Pakistani Transitional Government prolonged the timeframe to March 31, 1949; and even before time, on March 28, by the Adoption of Federal Legislation and Ordinance Order, the whole Indian Civil code had been incorporated, taking into account the modifications that occurred after division.

Under the Pakistan Order 1947, a Federation had been formed that indulged the 4 unit (provinces) of NWFP (North-Western Frontier Province) and Sindh, West Punjab, Balochistan and East Bengal East Bengal, West Punjab, Sind, along with some other territories like Karachi along with any Indian states that could capitulate to Federal state. The organization was based upon that Government of India Act of 1935, and it had been proposed that independent units be established as component parts of State. Because consolidation was discovered to be difficult and detrimental both to organizational effectiveness, the underlying principle behind it was provincial independence. The national government progressively delegated many of its authorities to provinces while maintaining control over a little core matters (Owen, 2003).

\section{The Constitution of 1956}

Finally after 9 years, Pakistan adopted her first constitution in 1956. It was passed on 23 $3^{\text {rd }}$ of March in 1956. The constitution named Pakistan as The Islamic Republic of Pakistan. The constitution had 234 Articles and 6 Schedules. All the principles, frameworks, division and management of powers had been outlined in these articles and schedules. All that said, the shadow of Govt. of India Act. 1935, was seen in it. There were a lot of articles in it that resembled the 19635 Act. The charter also had a few lapses and setbacks. Like, it was party flexible and partly rigid. The procedure of amendments was not so hard and could easily be amended. The major issue with the constitution was of Language. Urdu and Bengali was national languages. Then lapses like lack of leadership and lack of political training were also there. Then Bengali's thought that they were under represented. The provinces were not given the provisional autonomy under the one unit scheme. Thus the constitution failed to get the popular acceptance and it was revoked in 1958 with Martial Law (Baxter, 1974).

\section{The constitution of 1962}

The 1962 constitution was the $2^{\text {nd }}$ charter drafted after 1956 Constitution. Pakistan had its $2^{\text {nd }}$ charter just within the time space of 6 years. Then the President of Pakistan Ayub Khan who revoked the 1956 constitution in 1958 waited some time 
for the public sentiment to go in his favor. Then under the supervision of Justice Shahab-ud-din, he formed a legislative commission. The report of the commission was then forwarded to Justice Manzoor Qadir, who drafted and designed the entire constitution of 1962. Thus, Ayub enacted the constitution on $8^{\text {th }}$ of July, 1962 after bypassing the presidential ordinance. The constitution had Urdu and Bengali as national Languages.

It was in written form. It contained all the information about the institutions of the state. The constitution was president friendly. The amendment was easy to be passed if it had the support of the president, otherwise, the process was much difficult. The bill brought to assembly had to had $2 / 3^{\text {rd }}$ majority to pass the bill and later to be sent to the president for approval. If he doesn't take any action within 30 days, the bill was to be considered passed. If he decided not to approve it, it was to be sent back to assembly and need $3 / 4^{\text {th }}$ of the majority of the assembly to pass. Then president had to react within 10 days. If not then he had to promulgate the opinion of Basic Democrats. Thus in the case of promulgation, the judgment of Basic Democrats was to be taken as final (Rashiduzzaman, 1969).

\section{Constitution of 1973}

With constant military coups and failure of previous constitutions, Pakistan was in dire need of something consolidated to keep the state matters intact and explicit. Pakistan was dismembered in 1971 with the separation of East Pakistan, in the shape of Bangladesh. Pakistan was then able to draw a unanimous constitution in 1973. Most of the provisions in it mirrored the previous constitutions. Although it had continued the same federal structure as in the previous ones, but unlike the previous ones, it created parliamentary system. The senate was constituted on 60 members, whereas the National Assembly consisted of 200 members. The upper house Senate, equally represented all the four provinces, whereas, the allocation of national assembly seats were based upon the ratio of population (Khan, 2010).

This time there was no dispute over language as Urdu became the national language. Punjab being the largest Province on the basis of population got more seats than the other provinces. Where Urdu became the national language, Sindh replaced Urdu with Sindhi as provincial language. The Federal State system was clearly defined by the constitution. The government was divided into two parts: Provincial and Federal. Since federal state government had 4 units, each got 14 member representation in the upper house (Senate). The senate members had granted term of 4 years, while half of the members were to be retired after 2 years. There were total of 67 matters those were to be handled by the Federal Government, while rest were in the court of Provinces. In the case of any sort of conflict between the center and provinces, the interest of center was to be prevailed as per the constitutional article of 143 (Kundi and Jahangir, 2002). 
Then CCI Council of Common interests came into existence to help the federation setup to develop and reinforce. The Council was the platform where the representatives of federal government and provinces were to sit to address the issues and matters. One of the major functions of the Council was to address the issues regarding natural resources like water, gas, energy and fuel etc. Railway was also added in the list for the policy making. Then PM Zulfiqar Ali Bhutto addressed to the nation after the enforcement of Constitution that it marked the end of military regimes and coups in the state and the democracy has been prevailed in its true nature. Yet corruption and misuse of power cases arose as the Ex. CM of Balochistan was jailed on the charges of corruption. Since it has been adopted, the constitution of 1973 has been functional in the State to Date. The constitution has been amended many times in the later years. The $8^{\text {th }}$ Amendment, the $17^{\text {th }}$ Amendment, and the $18^{\text {th }}$ Amendment are the most prominent ones (Mukhtar, 2016).

\section{Conclusion}

The federal history of Pakistan has been full of ups and downs, and it has taken all the tipsy topsy ride. The true nature of Federal system is yet to be met in the state, but many attempts have been done in order to make the state functional as a Federal entity. Failure of different constitutions, military coups, linguistic disagreements, dismemberment of East Pakistan, and inconsistency of democratic process has badly affected the Federal process in Pakistan. The 1973 Constitution where gave the hope that there would be stability now in the Federal system, amendment like $18^{\text {th }}$ Amendment has further taken away the power from Center leaving it as type of a puppet in the hands of provinces.

When we analyse the federal history in Pakistan, it is clearly evident that all the failures of the past in the constitutional history have led the country towards failure of federalism in the country. All the constitutions e.g. 1956, 1956, and 1973 were supposed to safeguard the federalism in Pakistan, yet were not successful enough in doing so. The differences between Center and Provinces further added fuel to the fire. The state went into the state of chaos many a times. Military take overs also damaged the system. Separation of East Pakistan is a clear evidence that the state could not gel with its units from the very beginning. Further the divide of resources and powers also did not let the federalism to strengthen its grounds in the country. 


\section{References}

Ahmad, R. (2010). The Endemic Crisis of Federalism in Pakistan, the Lahore Journal of Economics Vol, 15: SE: pp. 15-31

Akbar, M. (2002). Federalism in Pakistan: Problems \& prospects. Asian and African Studies, 11(1), 37-48.

Ariyo, A. (2003). Theories of Federalism, Fiscal Policy and Growth in Africa: Fiscal Federalism, Decentralization and the Incidence of Taxation, Ad-Hoc Expert Group Meeting, Economic Commission for Africa, Addis Ababa, 7-9 October.

Baxter, C. (1974). Constitution making: The development of federalism in Pakistan. Asian Survey, 14(12), 1074-1085.

History of Pakistan. (2021). Government India Act of 1935. Retrieved from: historyofpakistan.com.

Hussain, S. S., Mustafa, G., Qasmi, H. A. U., \& Arslan, M. (2019). A Glance at Federalism of Pakistan in perspective of Linguistic, Economic, Fiscal and Ethnic Dimensions. Journal of Political Studies, 159-159.

Iqbal, K. (2020). Center-province Relation after the 18 th Amendment: A Case Study of Sindh. Thesis.

Khan, H. (2010). Constitutional and Political History of Pakistan. Karachi: Oxford University Press, p. 51.

Kundi, M. A., \& Jahangir, A. M. (2002). Federalism in Pakistan: Issues and Adjustment. Asian Affairs, 23-36.

Mukhtar, S. (2016). Social Transformation of Pakistan under the Constitution of 1973. Social Transformations in Contemporary Society. Lithuania. Mykolas Romeris University, 4, 47-59.

Naseer, S. (2007, August). Federalism and Constitutional Development in Pakistan.

Owen, N. (2003). The Conservative party and Indian independence, 1945-1947. The Historical Journal, 46(2), 403-436.

Rashiduzzaman, M. (1969). The National Assembly of Pakistan under the 1962 Constitution. Pacific Affairs, 42(4), 481-493. 
Tamuno, T. N. (1998). Nigerian federalism in historical perspective. Federalism and Political Restructuring in Nigeria. Ibadan: Spectrum.

Zulfqar, S. (2012). Politics of new provinces in Pakistan: Prospects and challenges. IPRI Journal, 12(2), 146-152. 